\title{
Field observations on feeding behavior in an Aruba Island rattlesnake (Crotalus durissus unicolor): Strike-induced chemosensory searching and trail following
}

\author{
MATTHEW GOODE \\ Houston Zoo, Houston, Texas \\ CHARLES W. RADCLIFFE \\ San Diego Zoo, San Diego, California \\ KAREN ESTEP \\ University of Colorado, Boulder, Colorado \\ ANDREW ODUM \\ Houston Zoo, Houston, Texas \\ and \\ DAVID CHISZAR \\ University of Colorado, Boulder, Colorado
}

\begin{abstract}
A free-ranging specimen of Crotalus durissus unicolor on Aruba Island was observed after striking rodent prey (Calomys hummelincki) and after no-strike presentations. Strike-induced chemosensory searching and trail following were seen after strikes. When a chemical trail was not present following a strike, the snake searched extensively near its refuge, but never emerged from it.
\end{abstract}

Numerous laboratory studies have demonstrated that rate of tongue flicking increases in rattlesnakes following the delivery of envenomating strikes but not after presentations of prey held just out of striking range (see Chiszar, Radcliffe, Scudder, \& Duvall, 1983, for a review). Since rattlesnakes typically release adult rodent prey following the strike, the snakes must then recover the carcass. The high rate of tongue flicking coupled with searching movements (collectively termed strike-induced chemosensory searching, or SICS) contributes to the trailfollowing task (Golan, Radcliffe, Miller, O’Connell, \& Chiszar, 1982). Only two field workers have so far seen these behaviors (Diller, 1990; Duvall, King, Graves, \&

This work was done under a grant from the Aruba Island Department of Agriculture and the AAZPA Species Survival Plan for the Aruba Island rattlesnake. C. W. Radcliffe wishes to thank Werner Heuschele, Director of the Center for Research on Endangered Species at the San Diego Zoological Society, Douglas Myers, Director, San Diego Zoo, and Thomas Schultz and Susan Schafer of the Herpetology Department, San Diego Zoo, for their support of his involvement in this project. A. Odum similarly wishes to thank John Werler, Director, Houston Zoo, Karl Peterson and Hugh Quinn of the Herpetology Department, Houston Zoo, and Tom Barmes, Aruba Island Department of Agriculture. A. Odum is now at the Department of Herpetology, Toledo Zoological Gardens, 2700 Broadway, Toledo, OH 43609. Reprints may be obtained from D. Chiszar, Department of Psychology, Campus Box 345, University of Colorado, Boulder, CO 80309.
Chiszar, 1986), and these were unplanned or chance observations made while the investigators were studying other phenomena. Consquently, the present opportunity to study SICS, trailing, and feeding in a free-ranging Aruba Island rattlesnake (Crotalus durissus unicolor) represents the first systematic field experiment on this behavior.

\section{METHOD}

Aruba Island, which is in the Dutch Lesser Antilles, contains the only known wild population of $C$. $d$. unicolor, although reproducing groups of the taxon are presently held in several zoos. This subspecies is endangered, and the American Association of Zoological Parks and Aquariums has organized a Species Survival Plan (SSP) to preserve it. This SSP is coordinated by Andrew Odum, and field work conducted on Aruba was designed to estimate the size of the present population, its distribution on the island, and the daily as well as seasonal activity patterns of the animals. These data will be reported elsewhere. The data reported here were gathered between May 8 and May 17, 1989, while we were tracking a free-ranging, radio-tagged, adult specimen.

The snake had positioned itself under an exposed root in a thick stand of bushes (Acacia tortuosa). The snake's head was clearly visible to the investigators, and its willingness to take rodent prey was confirmed by pilot tests. Four trials were then conducted in random order (intertrial interval $=2$ days). In two of these, live-trapped mice (Calomys hummelincki) were suspended by forceps and held just out of the snake's striking range (about $15 \mathrm{~cm}$ ) for $5 \mathrm{sec}$. The mice were then removed. In one of the trials, no chemical trail was deposited as the mouse was moved away. During the second observation, the mouse was removed by dragging it along the substrate, thereby creating a chemical trail about 

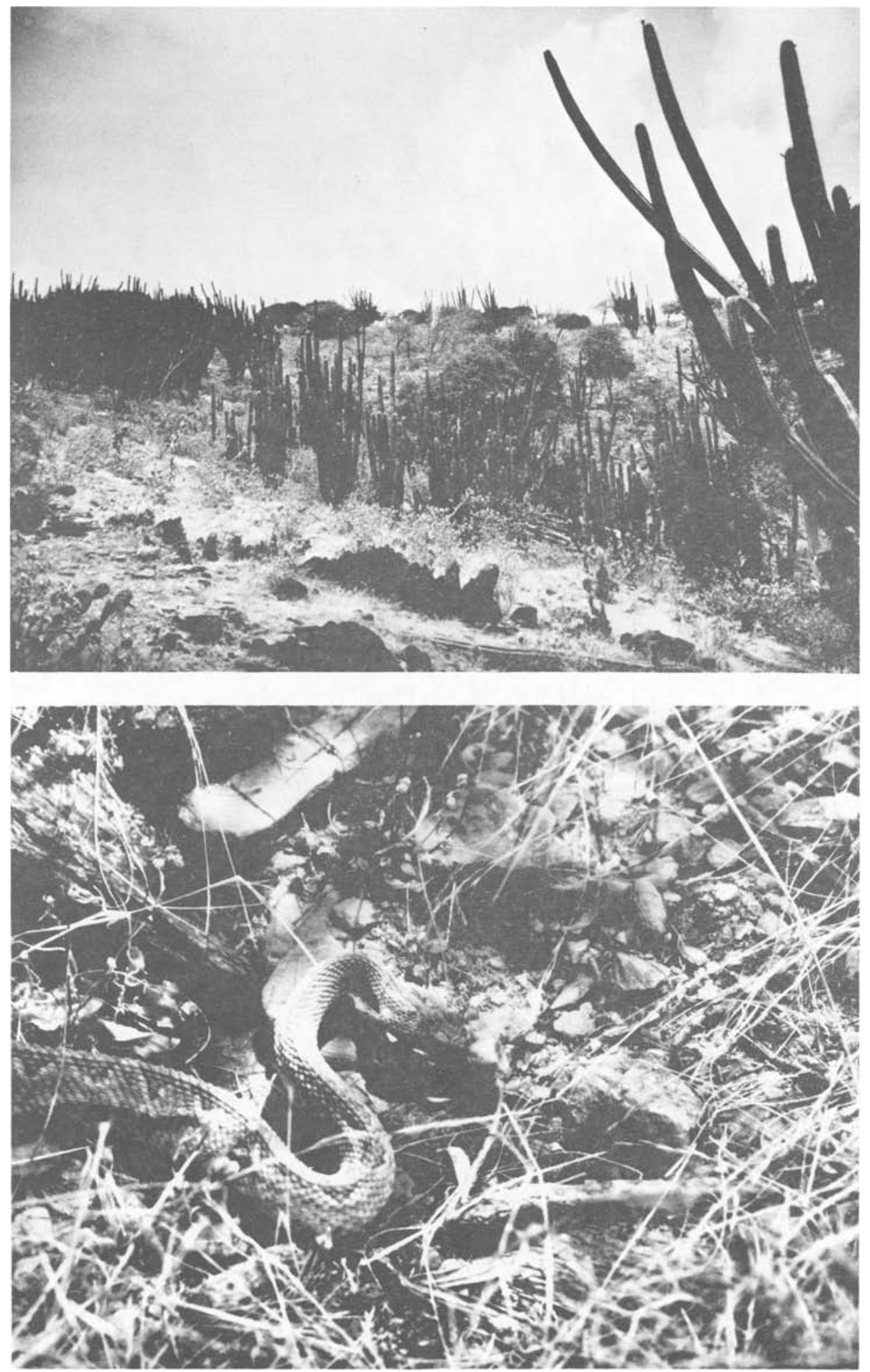

Figure 1. Top: Xeric habitat of Crotalus durissus unicolor on Aruba Island, Dutch Caribbean. Bottom: The specimen studied here, upon arriving at the rodent carcass in the strike-trail condition (see Table 1). 
Table 1

Rate of Tongue Flicking and Latency to Locate Carcasses on Each of Four Trials by a Free-Ranging Aruba Island Rattlesnake

\begin{tabular}{|c|c|c|c|c|}
\hline \multirow[b]{2}{*}{ Presentation } & \multirow[b]{2}{*}{ Latency } & \multirow{2}{*}{$\begin{array}{c}\text { Carcass } \\
\text { Recovered }\end{array}$} & \multicolumn{2}{|c|}{ Mean Tongue Flicks } \\
\hline & & & Min 1-3 & Min 1-20 \\
\hline \multicolumn{5}{|c|}{ No Chemical Trail } \\
\hline $\begin{array}{l}\text { No Strike } \\
\text { Strike }\end{array}$ & $\begin{array}{l}20 \\
20\end{array}$ & $\begin{array}{l}\text { no } \\
\text { no }\end{array}$ & $\begin{array}{r}0.3 \\
51.3\end{array}$ & $\begin{array}{r}0.1 \\
24.8\end{array}$ \\
\hline \multicolumn{5}{|c|}{ Chemical Trail } \\
\hline $\begin{array}{l}\text { No Strike } \\
\text { Strike }\end{array}$ & $\begin{array}{l}20 \\
3.0\end{array}$ & $\begin{array}{l}\text { no } \\
\text { yes }\end{array}$ & $\begin{array}{r}6.0 \\
47.3\end{array}$ & 1.9 \\
\hline
\end{tabular}

$150 \mathrm{~cm}$ long. In the latter case, a euthanized mouse was placed at the end of the trail, whereas in the former case, a euthanized mouse was placed at the same spot (but of course no trail led to it). Two additional trials were run. These were exactly like the ones just described, except that the snake was permitted to strike the initial stimulus mice after the 5 -sec presentations. The following dependent variables were recorded: (1) rate of tongue flicking during the $5 \mathrm{~min}$ preceding each trial (baseline data); (2) rate of tongue flicking during the $20 \mathrm{~min}$ following presentation of stimulus mice or until the snake located the carcass and began to eat; and (3) latency to locate the carcass.

\section{RESULTS}

The rate of tongue flicking prior to presentation of stimulus mice was 0.0 on all trials, indicating that the snake was quiescent. All remaining data are summarized in Table 1. No-strike presentations were followed by low rates of tongue flicking and failures to locate rodent carcasses within $20 \mathrm{~min}$. In fact, the snake never moved from its initial position during these trials. Strike presentations, however, were followed by high rates of tongue flicking. When no chemical trail was present in the poststrike environment, the snake searched all about the trunk under which it was located, but the animal never moved its tail out of its retreat. Only the snake's head moved about. Eventually, the snake quit flicking its tongue and coiled its body back into the initial retreat. When a chemical trail was available, however, the snake found it $120 \mathrm{sec}$ after the strike (this corresponded to tongue flick No. 90). During the next $60 \mathrm{sec}$, a total of 52 tongue flicks were emitted, $40(76.9 \%)$ of which were directed to the chemical trail as the snake moved directly to its termination (Figure 1).

\section{DISCUSSION}

These data agree with laboratory results on SICS and trail following in rattlesnakes, providing field validation for the earlier lab studies (see O'Connell, Greenlee, Bacon, \& Chiszar, 1982). Perhaps the most interesting result came from the strike-no-trail condition, in which rate of tongue flicking increased sharply but the snake, finding no trail, refused to leave its station. The implies that an elevated rate of tongue flicking is an obligate consequence of striking prey, agreeing with previous arguments that SICS represents a modal action pattern (Golan et al., 1982; cf. Barlow, 1977). Another implication of this performance is that the snake was strongly committed to cover, being willing to leave it only when a payoff was reasonably assured by the presence of a prey trail. Prairie rattlesnakes (Crotalus viridis), by contrast, are typically willing to search away from cover under strike-no-trail conditions (Chiszar, Radcliffe, \& Feiler, 1986; Golan et al., 1982). Hence, if the behavior of the present specimen of $C$. $d$. unicolor is representative of its population, these snakes differ in an interesting way from $C$. viridis.

Further speculation about the behavior of Aruba Island rattlesnakes is unwarranted at this time. Instead we encourage further efforts to protect this seriously endangered population and we urge investigators to incorporate studies of basic ethology into their assessments of population dynamics. In this way, we will learn not only about the reproductive potential of the population, but also about its necessary resources. This knowledge might lead to techniques for artificially enhancing the existing resource base or for creating suitable conditions in places where resources currently are inadequate.

\section{REFERENCES}

BARLow, G. W. (1977). Modal action patterns. In J. Sebeak (Ed.), How animals communicate (pp. 98-134). Bloomington: Indiana University Press.

Chiszar, D., Radcliffe, C. W., \& Feiler, F. (1986). Trailing behavior in banded rock rattlesnakes (Crotalus lepidus klauberi) and prairie rattlesnakes (Crotalus viridis viridis). Journal of Comparative Psychology, 100, 368-371.

Chiszar, D., Radcliffe, C. W., Scudder, K., \& Duvall, D. (1983). Strike-induced chemosensory searching by rattlesnakes: The role of envenomation-related chemical cues in the post-strike environment. In D. Müller-Schwarze \& R. M. Silverstein (Eds.), Chemical signals in vertebrates (pp. 1-24). New York: Plenum.

Diller, L. (1990). A field observation on the feeding behavior of Crotalus viridis lutosus. Journal of Herpetology, 24, 95-97.

Duvall, D., King, M. B., Graves, B. M., \& Chiszar, D. (1986, June). High, short-season, patchy deserts: Causes of active foraging in an "ambusher," the prairie rattlesnake (Crotalus viridis viridis). Paper presented at meeting of the Animal Behavior Society, Tucson, AZ.

Golan, L., Radcliffe, C. W., Miller, T., O'Connell, B., \& ChIsZAR, D. (1982). Trailing behavior in prairie rattlesnakes (Crotalus viridis). Journal of Herpetology, 16, 287-293.

O'Connell, B., Greenlee, R., Bacon, J., \& Chiszar, D. (1982). Strike-induced chemosensory searching in old-world vipers and newworld pit vipers at San Diego Zoo. Zoo Biology, 1, 287-294. 